\title{
Hazard Analysis Critical Control Points (Haccp) in the Production of Soy-kununzaki: A Traditional Cereal- Based Fermented Beverage of Nigeria
}

\author{
Danbaba Nahemiah ${ }^{1, *}$, Oyeleke Solomon Bankole ${ }^{2}$, MajiAlhassan Tswako $^{3}$, Kolo Isa Nma-Usman ${ }^{4}$, \\ Hauwawu Hassan ${ }^{3}$, Kolo Isa Fati ${ }^{5}$ \\ ${ }^{1}$ Food Technology and Value Addition Research Program, National Cereals Research Institute (NCRI), Badeggi, PMB 8, Bida, Niger \\ State, Nigeria \\ ${ }^{2}$ Department of Microbiology, Federal University of Technology, PMB 65, Minna, Niger State, Nigeria \\ ${ }^{3}$ Research Operations Department, National Cereals Research Institute (NCRI), Badeggi, PMB 8, Bida, Niger State, Nigeria \\ ${ }^{4}$ Research Outreach Department, National Cereals Research Institute (NCRI), Badeggi, PMB 8, Bida, Niger State, Nigeria \\ ${ }^{5}$ Department of Food Science and Technology, Federal University of Technology, PMB 65, Minna, Niger State, Nigeria \\ *Corresponding author: dnahemiah@gmail.com
}

Received October 20, 2014; Revised November 03, 2014; Accepted November 24, 2014

\begin{abstract}
In this study, Hazard Analysis Critical Control Point (HACCP) was adopted for the evaluation of food safety hazards in the production of local cereal-based beverage (soy-kununzaki) consumed in Nigeria. Significant quantity of physical hazards were recorded when about $1 \mathrm{~kg}$ of production materials were analysed. $2.35 \%$ stones pieces, $1.25 \%$ pieces of plastic materials, $1.95 \%$ metallic materials, $7.00 \%$ soil, $5.69 \%$ weed seeds, $1.55 \%$ broken grains of soybean were the main physical hazards of concerned identified, while biological physical hazards includes $2.26 \%$ animal waste and $2.15 \%$ insects. Microorganisms of public health importance were also isolated. Critical control points in the beverage production were highlighted and process capability determined. Process capability index (Cp) was approximately 1.7 for bacterial count and 1.6 for coliform, indicating that the process can be considered capable. Hence HACCP would help in improvement of quality and safe beverage production when properly applied.
\end{abstract}

Keywords: beverage, soy-kununzaki, hazards, food safety, critical control points

Cite This Article: Danbaba Nahemiah, Oyeleke Solomon Bankole, MajiAlhassan Tswako, Kolo Isa NmaUsman, Hauwawu Hassan, and Kolo Isa Fati, "Hazard Analysis Critical Control Points (Haccp) in the Production of Soy-kununzaki: A Traditional Cereal-Based Fermented Beverage of Nigeria." American Journal of Food Science and Technology, vol. 2, no. 6 (2014): 196-202. doi: 10.12691/ajfst-2-6-5.

\section{Introduction}

The Hazard Analysis Critical Control Point (HACCP) has been recognized as more effective food quality control strategy than the conventional end-product sampling practices, because it places more emphases on prevention and control of potential hazards [39] The HACCP approach to food safety management is recommended by the International Commission on Microbiological Specification for Foods [13], the National Advisory Committee on Microbiological Criteria for Foods [8], and the Codex Alimentarius Commission [21] and is being instituted throughout the world [29]. The HACCP is based on seven key principles: the potential hazards in foods are identified and their risks assessed; Critical Control Point (CCP), the point in the process where control could be exercised to minimize or eliminates the potential hazards, are identified; specifications are established for each CCP; corrective action to be taken when deviation occur at the CCP are identified; a record is kept of the process flow chat; and verification procedures are put in place to ensure that the HACCP is functional capable of controlling hazards. Thus, HACCP identifies hazards and preventive measures for their control. Its effect is to focus control at the CCPs, and to provide a bases on which the performance of food production system and the expected safety of the food processed by it can be assessed immediately by the processes $[3,36]$. According to these principles, a risk assessment will be taken into consideration: the evidence of hazard to health; the microbiology of the food; the likelihood and consequences of microbiological contamination and/or growth during subsequent handling, storage and use; the category of consumers at risk; and, cost-benefit rational associated with the application of the specification [29].

Киnu, a generic name used in describing all kinds of non-alcoholic beverages (cereal-based) with specifications usually attached to denote the basecereal grain. Kununzaki therefore, refers to sweet kunu, which is a traditional nonalcoholic beverage consumed widely in the northern part of Nigeria $[7,23]$. It is usually spiced with ginger, cloves, red pepper, black pepper, and cinnamon which are 
collectively known as kayanyaji in Hausa language. Its production is traditionally carried out in small-scale, being made widely and served as beverage for visitors or sold by street vendors as beverage.

To improve the nutritive value of the product, legumes are added as a means of increasing its protein content. A great deal of fruitful research is being carried out on plants as cheap source of protein, minerals and vitamins in most parts of the World([17]. The usefulness of legume in the production of high protein foods in meeting the needs of the vulnerable group of the population is now well recognized, and several high protein foods have been developed industrially in different parts of the World. The high costs of these industrially developed high protein foods makes them out of reach for the low and average income persons in Africa [7]. Alternatives for the processing of industrially produced high protein foods that will meet the needs of all in Africa seems to be the increased use of improved traditional food preparation techniques [2,7]. An improved technique for the production of a cereal-based beverage enriched with soybean has been developed at the National Cereals Research Institute (NCRI), Badeggi, and similar work has been carried out at the Federal Institute of Industrial Research (FIIRO), Oshodi, Lagos. The new technology involves the addition to the cereal base soybean for the production of kununzaki [23,24].

Kununzaki is popular among the people of the northern part of Nigeria. Women earn considerable amount of income in selling this product, which has improved their livelihood has improve their livelihood, hence process and product optimization would improve the quality of this product and this in turn would imply more patronage and income, which is the cardinal point of the government poverty eradication program, under the Millennium Development Goal (MDG) Challenges in Nigeria. Kununzaki has been popular because of its characteristic sour-sweet taste and milky-creamy appearance, and its low viscosity and cost compared with the readily available carbonated beverages, which are beyond the reach of an average Nigerian. Since consumption and popularity are high, the nutritive and safety characteristics of this product should be of up most priority with regard to its regulation. The quality and safety issues are important so that markets are not compromised by the sale and consumption of low quality, unsafe and substandard foods. For the safety of human foods, food borne pathogens constitutes the greatest hazards. The Hazard Analysis Critical Control Point (HACCP) program is becoming an international requirement for the development and registration of foods. The Codex Alimentarius Commission, the International Food Standard-setting body overseen by the United Nation (UN) agencies, the Food and Agricultural Organization (FAO), and World Health Organization (WHO), have recommended HACCP adoption all over the World [30,39]. Food industries are rushing to implement the process to insure the safety of their product and meet the stringent quality assurance requirement of the international and local standard organizations to survive in the competitive World food market [15]. Hence the need to conduct research into a cheap, adaptable and sustainable quality management protocol and microbial control technique for the production of a widely consumed ready-to-eat food like soy-kununzaki.
The objective of this study is therefore, to conduct hazard analyses for soy-kununzaki preparation, identification of Critical Control Points (CCPs), develop production flow chart showing the critical control points, identification and characterization of microorganisms at the critical control point levels this we believe will improve its safety and up scaling for industrial production.

\section{Materials And Methods}

\subsection{Materials}

Materials for this research were soybeans (Glycine max), peal millet (Pennisetumtyphodeum), ginger (Zingiberofficinale), black pepper (Pippersp), clove (Euginiacaryophyllata) and cinnamon (Xylopiaaethiopica). Sample of soybean were obtained from the seed store of the National Cereals Research Institute (NCRI), Badeggi, while ginger, millet, clove, black pepper and cinnamon were bought from the modern market Bida, Niger State. Five independent commercial producers of Soy-kununzaki (A, B, C, D, and E) were observed while producing the product; the weight of the ingredients used by individual producer was noted. Samples were taken aseptically and maintained at temperature ranging between $0-4.4^{\circ} \mathrm{C}$ until analysed. The following media were used for microbiological studies, Nutrient agar (NA), for total viable bacteria counts, Eosin Methylene Blue agar (EMB) for coliform counts, and SabroudDextrose Agar (SDA) for yeast and fungal counts. Each medium was prepared according to the manufacturer's specification and sterilized by autoclaving at $121^{\circ} \mathrm{C}$ for 15 minutes. One percent streptomycin was added to the SDA after sterilization to inhibit the growth of bacteria [31].

\subsection{Pre-treatment of Samples}

Soybeans were sorted and cleaned manually before blanching in boiling water for about 10 minutes; the blanched seeds were then soaked in tap water for about 6 hours and washed in clean tap water after soaking. The millet grains were sorted, before soaking in tap water at ambient temperature $\left(32 \pm 22^{\circ} \mathrm{C}\right)$ for about $8 \mathrm{hr}$ and washed to remove stones, soils, glass, plastics and other foreign material found in it. The spices were cleaned and dried.

\subsection{Laboratory Preparation of Soy-kunuzaki}

After pre-treatment, the resulting paste from wet milling was then divided into three portions. One part was left standing, while two parts werecooked by the addition of boiling water. The cooked paste was allowed to cool to about $45 \pm 2^{\circ} \mathrm{C}$ before mixing $(2: 1 \mathrm{v} / \mathrm{v}$ ratio) with the uncooked portion, which serves as a source of inoculum. The mixture was then sieved with muslin cloth in excess water followed by further dilution with two-volumes of water. The filtrate (soy-kununzaki) wasthen allowed to ferment for 8-10 hours, which was then sweetened with sugar crystals to taste.

\subsection{Hazards Analysis}

The hazard analysis method of [28] was adopted to observe soy-kununzaki preparation and to identify possible sources and mode of contamination, collect samples at 
each stage of the production process and testing them chemically, physically and microbiologically and document standard flow chart of soy-kununzaki processing and indicating hazards and critical control points. 200g of the raw materials were randomly sampled and the particulate matters present in the sample wascounted manually and recorded as percentage physical hazards. Samples were taken at each stage of production and $\mathrm{pH}$, TTA and TSS were analysed.

\subsection{Critical Control Points (CCP)}

The critical control point decision tree as developed by the Codex Alimentarius Committee on Food Hygiene [21] and modified by [20] was used to identify the critical control points out of the many trivial hazards points identified during the hazard analysis.

\section{Chemical Analysis}

\subsection{Determination of $\mathbf{p H}$}

The $\mathrm{pH}$ values were measured using a referenced $\mathrm{pH}$ meter (Model 291 mk2 PYE UNICAM, England) after standardization with $\mathrm{pH} 4$ and $\mathrm{pH} 7$ buffers. Values were recorded as the meter becomes steady. The meter electrode wasfirst dipped into a buffer solution before dipping into sample for analysis; the pHwasread on the meter automatically.

\subsection{Determination of Total Titratable Acidity (TTA)}

Titratable acidity was determined using the method described by Pearson (1991). 10ml of soykunuzakiwaswasina volumetric flask and three drops of phenolphthalein indicator were added and the flask thoroughly shaken. This was titrated against $0.1 \mathrm{~N} \mathrm{NaOH}$ to a pink colour end-point. Total titratable acidity was expressed as lactic acid;

Titratable acidity $=$ titer value $(\mathrm{ml})$ x 0.009 lactic acid

\section{Microbiological Analysis}

\subsection{Total Viable Counts}

One gram of each of the ingredients (soybeans, millet, ginger, loves, black pepper and cinnamon) and product blend at each stage of the processing was crushed or homogenized in $9 \mathrm{ml}$ of sterile distilled water. The mixture was then vigorously shaken to obtain a $10^{-1}$ food homogenate. From these serial dilutions were prepared for $10^{-2}$ to $10^{-6}$ dilutions. $10^{-6}$ dilution was used for plating. Total plate count was then estimated by the pour plate technique. The dilutions in the test tubes were plated in duplicates in Petri dishes, one millilitre from each dilution, was placed aseptically in a sterile Petri dish. Molten (15ml) nutrient agar was poured into Petri dishes. This was carefully shaken to mix the sample with agar and allowed to solidify at room temperature $\left(32 \pm 2^{\circ} \mathrm{C}\right)$. The plates were turned over after solidification and incubated at $37^{\circ} \mathrm{C}$ for 48 hours. Distinct colonies formed on the agar plates counted, averaged and expressed as Colony Forming Units per $\mathrm{ml}(\mathrm{CFU} / \mathrm{ml})$.

\subsection{Coliform Counts}

One millilitre $(1 \mathrm{ml})$ each of the dilution was serially diluted samples were plated on EMB agar for the enumeration of coliforms. The plates were incubated at $37^{\circ} \mathrm{C}$ for $24-48$ hours. The colonies that developed in the plates were counted and recorded as colony forming unit per millilitre of sample (CFU/ml).

\subsection{Mold/Yeast Counts}

Serially diluted samples taken from the raw materials, products at each point of processing were inoculated into Petri dishes $(1 \mathrm{ml})$ and molten SDA was poured and allowed to solidify before incubating at room temperature for 48 to 96 hours. The colonies that developed in the plates were counted and recorded as the colony-forming unit per millilitre or gram $(\mathrm{CFU} / \mathrm{ml})$. Series of sub culturing were made for all the counts to obtain pure culture isolates. Each isolates was grown on a nutrient agar slant and stored for next test, characterization and identification.

\subsection{Statistical Analysis}

Data collected were subjected to analysis of variance (ANOVA). This was used to evaluate variation in terms of changes in microbial count and chemical parameters at each stage. Probability level was maintained at 0.05 (confidence limit) [14]. While Least Significant Difference Test (LSD) was used to test significance within the means of the treatments [37].

\section{Results and Discusion}

\subsection{Identification of Hazards and Critical Control Points}

Table 1 shows details of the hazard analysis of Soykununzaki production and its critical control points (CCPs). Significant quantity of physical hazards were recorded when about $1 \mathrm{~kg}$ of production materials were analysed. $2.35 \%$ stones pieces, $1.25 \%$ pieces of plastic materials, $1.95 \%$ metallic materials, $7.00 \%$ soil, $5.60 \%$ weed seeds, $1.55 \%$ broken grains of soybean were the main physical hazards of concerned identified, while biological physical hazards includes $2.26 \%$ animal waste and $2.15 \%$ insects (Table 1 ). There were also material, time and energy loses recorded at few other points in the process operation. While figure 1 shows details of the flow chart followed by all the processor in the production of Soy-kununzaki, it was monitored and the critical control points identified. The critical control point identified were washing operation, steeping of raw materials, milling operation, sieving and holding of paste for fermentation, and packaging.

The presence of these hazards in excess of the acceptable limits is considered of high risk and may cause cuts, injury, bleeding, infections, trauma etc. Mechanical damage to the milling machine and sieving cloths may also occur, and may lead to time and material loss. 
Generally cleaning of utensils is carried out using detergents and is not often rinsed properly, presenting possible contamination of the product with detergent residues. The materials are not often closed and are exposed to absorption contaminants from air and other particulate materials from the environment.

Table 1. Hazards identified in the processing of Soy-kununzaki and its control points (CCP)

\begin{tabular}{|c|c|c|c|}
\hline Hazards* & Amount & Operations & ССР \\
\hline \multicolumn{4}{|l|}{ Physical } \\
\hline Stones & $2.35 \%$ & ST, CL & ST \\
\hline Plastics & $1.25 \%$ & , & ST \\
\hline Metals & $1.95 \%$ & , & ST \\
\hline Soils & $7.00 \%$ & , & ST \\
\hline Weed seeds & $5.60 \%$ & ,, & ST \\
\hline Broken grain & $1.55 \%$ & , & SK \\
\hline Temp. variation & - & SK, MS, STD & ST \\
\hline \multicolumn{4}{|l|}{ Biological } \\
\hline Animal wastes & $2.26 \%$ & ST, CL & ST, CL \\
\hline Insects & $2.15 \%$ & , & SK \\
\hline Microorganisms & - & all operations & CL MS, \\
\hline Microbial growth & - & all operation & SK, STD \\
\hline \multicolumn{4}{|l|}{ Chemicals } \\
\hline Residue from detergents & ob & Cleaning & CL \\
\hline Absorption from water & $o b$ & SK & SK \\
\hline Absorption from air & ob & SK, STD & STD \\
\hline Particulate from environment & ob & SK, STD, ML & STD \\
\hline \multicolumn{4}{|l|}{ Others } \\
\hline Waste to the environment & $o b$ & SK, ML, SV & SV, ML \\
\hline Material losses & ob & ML, SV & SV, ML \\
\hline Time losses & $\mathrm{ob}$ & ST, CL, STD & STD \\
\hline Energy losses & $o b$ & ML, MS & ML, MS \\
\hline
\end{tabular}

Hazards are physical, chemical and biological agents that are reasonably likely to cause illness, injury or loss in the absence of control.SK=Soaking, $\mathbf{M L}=$ Milling, $\mathbf{S V}=$ Sieving, $\mathbf{S T D}=$ Standing, MS=Mixing, and $\mathbf{C L}=$ Cleaning, $\mathbf{S T}=$ Sorting, ob $=$ observed .

The significant hazards identified in Soybean during sorting and washing includes mechanical damage to the grain itself, high microbial load, and the presences of poisonous and dead insects. When oil seed like soybean is damagedit disrupts the cell wall of the beans and this triggers a chemical reaction usually initiated by isoenzyme of lipoxygenase present in the cells of the beans. These isoenzymes oxygenate poly-unsaturated fatty acids containing cis-1, 4-pentadiene double bound located between the carbon 6 and 10 from the methyl end of the fatty acid. In the presence of linoleic acid the isoenzyme produces hydro-peroxide that may be responsible for the development of off flavour of the product. This therefore makes sorting a CCP that need tobe properly handled to avoid use of broken soybean seeds.

The dead insects may also impart off flavour and taste to the product if not removed. The injury that may be sustained as a result of the presences of these physical hazards in excess of the acceptable limits may require surgery to remove. Most of the physical hazards are removed during sorting and cleaning process that is given to material before going into the processing line. Therefore, HACCP approach is effective in prevention, elimination or reduction of these hazards to acceptable levels, this also agrees with the report of Foster, [32] and Buchaman, [22]who reported that sorting and cleaning operations are critical in the preparation of cereal-based products.

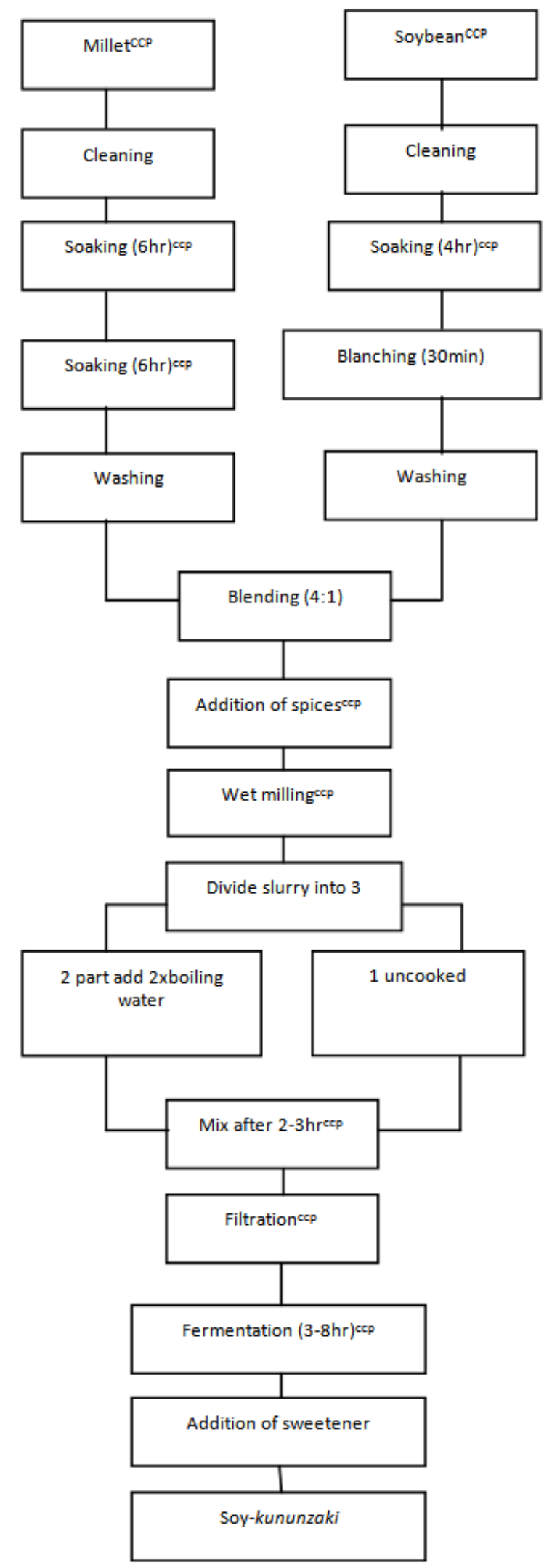

Figure 2. critical control points in the production of soy-kununzaki

The number of organisms isolated from the raw materials varied among materials (Table 2). Millet recorded the highest viable count $\left(1.68 \times 10^{3}\right)$ while clove recorded the lowest. In terms of coliform count, Cinnamon had the highest, followed by millet and the least was in ginger. Mold and yeast counts were greater in millet than all the raw materials and lowest in soybean, cinnamon, 
and clove. The presence of these organisms in these materials is an indication of their storage history.

Table 2. Number of microorganisms isolated on the raw materials used in the production of Soy-kununzaki

\begin{tabular}{lccc}
\hline Raw Material & $\begin{array}{c}\text { TVC } \\
(\mathrm{CFU} / \mathrm{ml})\end{array}$ & $\begin{array}{c}\text { CFC } \\
(\mathrm{CFU} / \mathrm{ml})\end{array}$ & $\begin{array}{c}\text { MYC } \\
(\mathrm{CFU} / \mathrm{ml})\end{array}$ \\
\hline Soybeans & $1.26 \times 10^{3}$ & $1.58 \times 10^{4}$ & $<1.00 \times 10^{1}$ \\
Millet & $1.68 \times 10^{3}$ & $2.98 \times 10^{3}$ & $6.20 \times 10^{3}$ \\
Ginger & $4.18 \times 10^{4}$ & $<1.00 \times 10^{1}$ & $2.21 \times 10^{3}$ \\
Black pepper & $1.43 \times 10^{3}$ & $2.72 \times 10^{4}$ & $1.10 \times 10^{3}$ \\
Cinnamon & $1.01 \times 10^{3}$ & $4.42 \times 10^{3}$ & $<1.00 \times 10^{1}$ \\
Clove & $<1.00 \times 10^{1}$ & $5.36 \times 10^{4}$ & $<1.00 \times 10^{1}$ \\
\hline
\end{tabular}

Values of three counts recorded as mean, TVC = Total Viable Count, $\mathrm{CFC}=$ Coliform Count. MYC $=$ Mold and Yeast

Microbiological hazards identified include bacteria, mold and yeast (Table 3 and Table 4). These organisms were associated with the raw materials used. ICMSF [13], Sanni, [2] and FDA [16] reported that many of these organisms are pathogenic, and occur naturally in the environment where foods are grown and processed.

Table 3. Bacteria isolated from raw materials used in the preparation of soy-kununzaki

\begin{tabular}{|l|l|}
\hline Raw materials & \multicolumn{1}{|c|}{ Microorganisms isolated } \\
\hline Soybean & Staphylococcus spp, Bacillus spp \\
\hline Millet & Shegillaspp, Lactobacillus spp \\
\hline Ginger & Klebsielaspp, Bacillus spp, Staphylococcus spp, \\
\hline Black pepper & Bacillus spp \\
\hline Cinnamon & Klebsielaspp, Bacillus spp \\
\hline Clove & Micrococcus spp, Staphylococcus spp \\
\hline
\end{tabular}

Table 4. Fungi isolated from raw materials used in the production of Soy-kununzaki

\begin{tabular}{|l|l|}
\hline \multicolumn{1}{|c|}{ Raw materials } & \multicolumn{1}{c|}{ Microorganisms isolated } \\
\hline Soybean & Aspergillusniger \\
\hline Millet & Aspergillusniger, Mucorspp \\
\hline Ginger & Penicillumspp \\
\hline Black pepper & Trichophytonspp, Penicillumspp \\
\hline Cinnamon & Rhizopusspp \\
\hline Clove & Trichophytonspp \\
\hline
\end{tabular}

The aim of washing in any food processing operation is to clean the surface of the raw materials to be used, to remove particulate materials and to reduce microbial load on them. Loss of control at this point could lead to the identified hazards in excess of acceptable limits. Unfortunately, the step that follows washing was not designed to eliminate or reduce the likelihood of the occurrence and extent of this hazard to food and consumer safety. Therefore, washing was judged as critical control point.

During the soaking process that follows, washing of the soaked soybeans and millet may reduce the identified hazards, but the soaking time of 8 to 10 hours allows for the rapid growth of the microbes present (Table 3). Also, the dissolved solids from millet and soybeans may serve as sources of nutrient for the propagation of these microbes. Loss of control at this stage may lead to the identified hazards in amount greater than the acceptable level of $10^{4-} 10^{3} \mathrm{CFU} / \mathrm{ml}$ in beverage. Milling which is the next step in the process was not designed to eliminate or reduce the microbial hazards to acceptable levels; hence, soaking is considered a critical control point.

Surprisingly, in all the processors monitored, none of them was seen washing their machine thoroughly before milling. Tomatoes, onion, beans, sorghum, and pepper are among the food materials that were milled in the machines the previous day. These materials have different microbial aspectwith soybeans, millet and spices used for Soykununzakipreparation, therefore, re-contamination, change in colour and taste of the product may occur, and this is not desirable. Unfortunately, the next step was not designed to eliminate or reduce the hazards. Therefore, milling process is considered a critical control point. The most important hazards of health risk identified during the sieving operation are the pieces of metals. This was learnt to be as a result of new disks used during milling. These fine metal pieces are of great health risk to the consumer. The presence of metal pieces in wet milled products agrees with the finding of Nilson et al., [34] and Karl, [10]. The water used to dilute the paste before sieving may probably serve as source microbial recontamination, since the next step cannot eliminate or reduce the hazards to acceptable levels, sieving is considered critical control point. Mixed pastes were kept at room temperature in an open container for 2-4 hours before sieving, and for 7-10 hour for fermentation. Holding foods at warm ambient temperature for 3 to 6 hours present high safety risk; the risk increases substantially with every hour of holding. Jideani, et al [12] reported that daytime temperature of less than $40^{\circ} \mathrm{C}$ at mid-day hours, were conducive for promoting microbial growth. The beverage is allowed to stand for over 8 hours to ferment the taste and flavour change during this period and preferred by most consumers, but holding the beverage at that temperature for that long allows for microbial proliferation (Table 5) and possible recontamination from the environment. Different processing steps favour microbial growth differently (Table 5).

Table 5. Change in the number of microorganisms counted at different stages of Soy-kununzaki production

\begin{tabular}{lccc}
\hline $\begin{array}{l}\text { Production } \\
\text { Stages }\end{array}$ & $\begin{array}{c}\mathrm{TVC}^{+} \\
(\mathrm{CFU} / \mathrm{ml})\end{array}$ & $\begin{array}{c}\mathrm{CFC}^{+} \\
(\mathrm{CFU} / \mathrm{ml})\end{array}$ & $\begin{array}{c}\mathrm{MYC}^{+} \\
(\mathrm{CFU} / \mathrm{ml})\end{array}$ \\
\hline Steeping (SB) & $4.26 \times 10^{4}$ & $1.85 \times 10^{3}$ & $3.27 \times 10^{4}$ \\
Steeping (ML) & $4.89 \times 10^{4}$ & $3.18 \times 10^{3}$ & $3.11 \times 10^{3}$ \\
Paste & $6.48 \times 10^{4}$ & $4.02 \times 10^{3}$ & $5.12 \times 10^{3}$ \\
Cooked +uncooked & $2.26 \times 10^{2}$ & $2.89 \times 10^{3}$ & $5.00 \times 10^{3}$ \\
Filtrate & $3.86 \times 10^{3}$ & $2.41 \times 10^{2}$ & $2.13 \times 10^{3}$ \\
Filtrate & $4.92 \times 10^{4}$ & $1.10 \times 10^{2}$ & $<1.00 \times 10^{1}$ \\
Filtrate & $5.64 \times 10^{4}$ & $1.18 \times 10^{2}$ & $<1.00 \times 10^{1}$ \\
Filtrate (final product) & $6.13 \times 10^{5}$ & $<1.00 \times 10^{1}$ & $<1.00 \times 10^{1}$ \\
\hline
\end{tabular}

$+=$ Value of three counts recorded as mean, TVC $=$ Total Viable Count, $\mathrm{CFC}=$ Coliform count, $\mathrm{MYC}=$ Mold and Yeast Counts.

Unfortunately no subsequent treatment was given to the beverage after this step to reduce or eliminate the hazards; hence, holding is considered critical control point. Soykununzaki are distributed with minimal packaging, they are mainly packaged in cellophane bag or plastic bottles. The processors were seen blowing the bag with their mouths; this is high-risk point as recontaminations with pathogenic microorganism of human origin are high. Packaging therefore, is considered critical control point.

Some of the microorganisms isolated (Bacillus spp, Listeria spp, Staphylococus)from the raw materials and the beverage during production(Tables 3 and 4) are of public health importance. The isolation of these organisms is in line with the work of Onuorah, et al., [6] who reported that Listeria spp, Staphylococcus spp and Bacillus spp are bacteria of significance in food borne diseases and they may cause some of the known bacterial food borne illnesses. Listeria monocytogeneshas since 
become recognized as an important food borne pathogens. According to Lovett and Twedt[9], specticemia is the most common listeric manifestation in adults. The isolation of these organisms in Soy-kununzaki agrees with the report of Anounye, [23], and Akoma, et al. [25]. Staphylococcus food intoxication is one of the most common food-borne illnesses giving rise to nausea, vomiting, abdominal cramping, prostration and diarrhea. Patel, et al., [4], Mason [35], Onuarah, et al., [6] and Efiuvweuwere and Akoma ([19] and [18]) all reported the contamination of raw materials used for kununzaki production by Staphylococcus. Toxins produced by Staphylococcus sppareareheat resistant to a certain extent, and therefore it is possible to have Staphylococcus food poisoning, having resisted the heat treatment during blanching and addition of hot water. The most important sources of Staphylococcus are the human. These buttress the report of WHO [1], that about $40 \%$ of normal human adults harbours these organisms in the nose and throat, hence the fingertips of human are often contaminated with these bacteria. Consequently, when contaminated foods are held for several hours at temperature well above $6.6^{\circ} \mathrm{C}$ the Staphylococci will grow and produce toxins. Therefore, personal sanitation by food processor and temperature at which the product is to be kept are considered critical. Some species of Staphylococcus are also considered lipolytic organisms. They are therefore, capable of causing hydrolytic and oxidative deterioration of the fat contained in the beverage. Bacillus spp are also proteolytic[27] and therefore produce variety of odour and flavour defects in the final product if not properly taken care of.Faparusi, et al., [33] have also reported the presence of Sacchaomycescerevisiae, Candida spp, and Aspergillusspp isolated on cereal grains. The difference in the types isolated at different stages of production by the different producers may likely be due to different environmental conditions under which the beverage were prepared and the type of organisms each individual producer might be harbouring. Aspergillusnigerand Aspergilusflavuswere the most isolated moldthroughout the production process, but Sacharomycescerevisiaedominate at the late stage of the process. Anon [26] reported the same trend; this may likely be as a result of increased acidity. The increased acidity may provide some assurance of microbiological safety of the product, as most of the organisms count reduced with increased acidity. But this may be doubtful since very high total viable population exceeding maximum levels recommended for beverage is not accepted. The numbers of bacteria isolates at different stages from different producer are higher than either the yeast or mold isolated, this could be due to environmental factors and the extent of contamination together with the fact that bacteria grow faster than yeast and fungi. Most of the bacteria isolated do not have any beneficial functions in beverage production, except for some Bacillus species involved in fermentation. Jideani and Osume [11] reported that some Bacillus spp are involved in fermentation in some local alcoholic beverages. The yeasts are involved in the fermentation process. Isolates such as Lactobacillus spp, Candida and Aspergillusapart from being contaminants, are reported to be involved in most fermentation process such as converting mash to wort. Torulopsisspecies are associated with food spoilage, being common contaminants in breweries. Although Lactobacillus spp. and yeast are not pathogenic, they may cause significant quality and economic losses, making their control desirable. The resulting change in acidity toward alkalinity during fermentation might be due to a reaction between sodium hydroxide with carbon dioxide from the atmosphere and/or from soybean and millet seeds respiration (Table 6). These changes in $\mathrm{pH}$ buttress the finding of Koseki and Itoh, [38]. It is also noted that some materials of the soaked soybeans and millet dissolve in the soak water, some of this materials might have brought about the decrease in acidity.

The change in $\mathrm{pH}$ and TTA during fermentation has significant $(p=5 \%)$ effect on the number and type of organisms that will grow in the soy=kununzaki.

Table 6. Change in chemical properties of soy-kununzaki during fermentation

\begin{tabular}{cccc} 
Fermentation time $(\mathrm{hr})$ & $\mathrm{pH}$ & TTA & TSS \\
\hline 0 & $6.314^{\mathrm{a}}$ & $0.180^{\mathrm{g}}$ & $14.140^{\mathrm{a}}$ \\
2 & $6.122^{\mathrm{a}}$ & $0.274^{\mathrm{f}}$ & $13.388^{\mathrm{ab}}$ \\
4 & $5.538^{\mathrm{b}}$ & $0.382^{\mathrm{e}}$ & $12.592^{\mathrm{bc}}$ \\
6 & $4.230^{\mathrm{c}}$ & $0.482^{\mathrm{d}}$ & $11.820^{\mathrm{c}}$ \\
8 & $4.038^{\mathrm{cd}}$ & $0.604^{\mathrm{c}}$ & $9.646^{\mathrm{d}}$ \\
10 & $3.804^{\mathrm{de}}$ & $0.706^{\mathrm{b}}$ & $8.812^{\mathrm{de}}$ \\
12 & $3.634^{\mathrm{e}}$ & $0.820^{\mathrm{a}}$ & $8.220^{\mathrm{e}}$ \\
\hline
\end{tabular}

Value of three recorded as mean. Mean of the same column followed by different letter differs significantly according to Duncan's Multiple Range Test at $5 \%$ level of probability.

For the HACCP process to be seen to be able to check quality of the products, test for the process capability was conducted, the process of the laboratory preparation steps are used and the limits set by WHO are used as upper and lower specifications. The upper and lower specifications are $10^{3} \mathrm{CFU} / \mathrm{ml}$ and $10^{4} \mathrm{CFU} / \mathrm{ml}$. The observed process mean of microbial count was $10^{2} \mathrm{CFU} / \mathrm{ml}$, and the standard deviation, $s$ is 0.988 . From this we can obtain our process capability (Cp) index. The upper and lower microbiological specification of raw agricultural products are $10^{4}$ and $10^{5}$ respectively, this specification also applies to finished cereal products like kunu, akamu, custard, pito etc.

$$
\begin{aligned}
& \text { Therefore, for bacterial counts, } \\
& \begin{aligned}
\text { Cp } & =\text { USL }- \text { LSL / 6s, } \\
& =10^{4}-10^{3} / 6 \mathrm{~s} \\
& =10^{4}-10^{3} / 6 \times 0.988 \\
& =10 / 5.928=1.687 .
\end{aligned}
\end{aligned}
$$

And for coliform count,

$$
\begin{aligned}
\mathrm{Cp} & =\mathrm{USL}-\mathrm{LSL} / 6 \mathrm{~s} \\
& =10^{4}-10^{3} / 6 \times 1.02 \\
& =10 / 6.12 \\
& =1.634
\end{aligned}
$$

Where $\mathrm{Cp}=$ Process capability index, USL = Upper specification limit, LSL = Lower specification limit, S = Standard deviation

It is often required to compare the output of process optimization within the process specifications recommended by regulatory agencies, and make statement about how well the process meets our objectives $[3,36]$ Statistically we assume that the results follow normality and therefore, the process capability index (Cp), as calculated was approximately 1.7 for bacterial count and 1.6 for coliform. [40] reported that for a process to be considered capable, the Cp would have to be at least 1.0 this means that the process HACCP is capable of controlling hazards in soy-kununzaki preparation if carefully implemented. 


\section{Conclusions}

Hazard analysis critical control point approach in quality management can be used in the preparation of the local beverage. The hazards identified are of great concern, and therefore their identification and documentation will go a long way in contributing to scholarly literature on this product. The critical control points identified will be a point for all processors of this product and similar to take maximum care so that safe food could be produce, which will increase consumer confidence and in turn more patronage. The presence of spoilage and contamination organisms is an indication that the produce is not produced under good hygiene practices and poses a serious health risk to its direct consumers. The HACCP approach therefore, has been shown to identify areas of concern where failure has not yet been experienced, making it particularly useful for new operation.

\section{References}

[1] WHO (2005). World Health Organization. FoodS afety. Development of hazard analysis critical control point system. Available at http://www.who.org.

[2] Sanni L, (1997). Quality Assurance System in the Food Industry Jedidiah Publishers, Abeokuta, pp17-30.

[3] Price, R.J., Tom, P.O., and Stevenson, K.E (1993). The Hazard Analysis Critical Control Point Way. University of California Press. Davis CA, 95616.

[4] Petal, J.D., ParthaSaarathy, N., Krishmagwamy, M.A and Nain, K.K (1976).Biochemical characteristics of some of the Coliforms from species.Journal of Food Science and Technology 13: 31-40.

[5] Pearson, M.E (1991). Composition and Analysis of Foods. Ed. Ronald, S. Kirk and Ronald Sawyer, Ninth Edition. 640-642.

[6] Onuarah, S.I., Adesiyun, A.A and Adeleke, J.o (1987).Occurrence of StaphilococcusandColiforms in kununzakiand utensils used in its preparation in Samaru Zaria.Journal of Food and Agriculture 1: 31-34.

[7] Nkama, I (1993).Traditional methods of production of high protein energy foods from grain legumes in the north-eastern state of Nigeria.Annals of Borno 10: 138-148. University of Maiduguri Press, Maiduguri, Nigeria.

[8] NACMCF (1992).HACCP System.National Advisory Committee on Microbiological Criteria for Food. International Journal of Food Microbiology. 16: 1-23.

[9] Lovett, J. and Twedt, R.M. (1998).Listeria- A scientific status summary by expert panel on Food Safety and Nutrition of the institute of Food Technologists. Pp 8-11., IFT, Chicago, IL.

[10] Karl, E.W (1987). Processing, nutritional and utilization of soybeans, In: soybeans for the Tropics. Ed. S.R. Singh, K.O. Bachie and K.E Dashiell, John Wiley and Sons Inc. 149-178.

[11] Jideani, I.A., and Osume, B.U (2001).Comprative studies on the Microbiology of three Nigerian fermented beverages - Burukutu, Pito and Nbal.Nigerian Food Journal 19: 25-33.

[12] Jideani, V.A., Nkama, I., Agbo, E.B and Jideani, I (2001). Identification of hazards critical control points in the traditional Furamanufacture. Nigerian Food Journal 19: 42 - 44.

[13] International Commission on the Microbiological Specification of Foods (ICMSF, 1986).Microorganisms in Food 2.sampling for microbiological analysis: principles and specific application. $2^{\text {nd }}$ ed., University of Toronto press. Available at http:www.cfsa.fda.gov/-dms/hret-toc.html.

[14] Gomez, K.A and Gomez, A.A (1984).Statistical Procedures for Agricultural research. $2^{\text {nd }}$ ed. International Rice Research Institute,. Whiley Interscience Publication. John Whiley and Son. NewYork.

[15] Food and Agricultural Organization (FAO, 1998).Understanding the Codex alimentarius. http//:www.foodsafety.who.int.html.
[16] FDA (2005). Food Safety inspection services.U.S. Food and Drug Administration, Washington .DC.

[17] El-Tinay, A.H., El-mahida, Z.M., El- Sombki, A (1985). Supplementation of fermented sorghum kisrabread with legume protein isolates. Journal of Food Technology20: 679-687.

[18] Efiuvweuwere B.J.O and Akoma, O (1997).The effects of chemical preservatives and pasteurization on the microbial spoilage and shelf-life of kununzaki.Journal of Food Safety. 17 203-213.

[19] Efiuvweuwere, B.J.O and Akoma, A (1995). The microbiology of kununzaki a cereal based beverage from northern Nigeria, during the fermentation (production) process World Journal of Microbiology and Biotechnology11: 491 - 493

[20] Dillon, M. and Griffith, C (1995).How to HACCP, an illustrated guide. MD Associate, 34a Hainton Avenue, Grimsby, UK pp 18

[21] CODEX (1993). Codex Alimentarius Commission: Codex Committee on Food Hygiene. Guideline for the application of hazard anlysis critical control point (HACCP) system (Alinorm 19/ 13A, Appendex B), Food and Agriculture Organization/ WHO, Rome http://www.codexalimentarius.net.

[22] Buchanan, R.L (1990). Hazard analysis critical control point (HACCP): A re-emerging approach to food safety. Trends in Food Science and Technology.Elsvier Science Publishers, Inc. pp $26-27$.

[23] Anounye, J.C (1997). Development and Evaluation of Soybeans-Millet blend for Soy-kununzaki preparation. MSc Thesis, Department of Food Science and Technology, University of Agriculture, Makurdi.

[24] Bankole, A.O and Olatunji, O (2001).Development of unfermented malted cereal - Soy beverage.Nigerian Food Journal19: 106-114.

[25] Akoma, O., Omuala, S.A., Ajiboye, M.O., Akoma, A.O and Alawoki, A. M (2002). The nutritive and sensory quality characteristics of kununzakiproduced with the addition of hydrolytic enzymes from malted rice (OryzaSativa).The journal of Food Technology I Africa 7 (1): 24-26.

[26] Anon, I (1980).Microbiology of Foods, Vol 1.Factors affecting life and death of microorganisms. New York: Academic press.

[27] Bjerklie, S. (1992). Hazard analysis critical control point in your plant:what HACCP is, what it isn't and how your operation can be affected. Meat and poultry38(2) 14-22.

[28] Bryan, F.L., Teupel, P., Riaz, S., Roohi, S., Quadar, F and Malik Z (1992b).Hazard analysis and critical control points of food preparation and storage in homes in a village in Pakistan.Journal of Food Protection55 (9): 703-713.

[29] Canadian Food Program (CFP, 2004). Proposed Microbial Standards for bottled water and package ice.A compendium of analytical methods. http://www.hc-sc.gc.ca/food-aliment/mh$\mathrm{dm} / \mathrm{mhe}$-e/compendium/eidex.html

[30] Canadian Food Program (CFP, 2002). Components of microbiolgical Criteria for Foods. www.hc-sc.gc.ca/fa.

[31] Fawole, M.O and Oso, B.A (1995).Laboratory Manual of Microbiology. Spectrum Books Limited, Ibadan, pp 14-56.

[32] Foster, E.M., (1989). A half century of Food Microbiology.Food Technology. 43(9) 208-215.

[33] Faparusi, S.I (1970). Sugar changes during production of burukutubeer. Journal of Science of Agriculture. 21: 79-81.

[34] Nelson, A.T. Wei, L.S and Stienberg, M.P (1979).Food from whole soybeans. In: World Soybean Research Conference II proceedings. Ed. Frederick, T.C, West view press, Boulder, Colorado. 745-776.

[35] Mason, A (1979). The hygienic quality of Spices Microbiological abstract14: 6651

[36] Stevenson, K.E (1990). Implementing hazard analysis critical control pointin the food industry.Food Technology Vol. 42(5): 179-180.

[37] Ignatius, U.O (1986). Statistical Method of detecting differences between treatment means.SNAAP Press (Nig); Enugu, 5-9.

[38] Koseki, S., and Itoh, K (2000).The effect of acidic electrolyzed water on the microbial counts in shredded vegetables.Journal of Japan Soc. Food.Sci.47: 907-913.

[39] Food and Agricultural Organization (FAO, 2004).Food safety management.Scientific certification system. http//:www.fooddag-haccp.html.

[40] Anonymous, (2005). Engineering Statistics Handbook available at http://www.who.int/foodsafety/publication.html. 